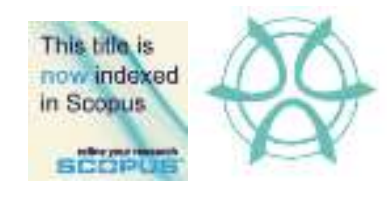

PLANNING MALAYSIA:

Journal of the Malaysian Institute of Planners

VOLUME 19 ISSUE 2 (2021), Page 121 - 130

\title{
BROWNFIELD SITES AND PROPERTY MARKET SENSITIVITY
}

\author{
Nur Zafira Zihannudin ${ }^{1}$, Nurul Hana Adi Maimun ${ }^{2}$ \& Nurul Liyana \\ Ibrahim $^{3}$ \\ ${ }^{1,3}$ Department of Real Estate, Faculty of Built Environment and Surveying \\ ${ }^{2}$ Centre for Real Estate Studies, Institute for Smart Infrastructure and \\ Innovative Construction \\ UNIVERSITI TEKNOLOGI MALAYSIA
}

\begin{abstract}
The existence of Brownfield sites is one of the main challenges that Malaysia must face due to financial, administrative and policy problems. The negative environmental and social impacts of Brownfield sites jeopardise residents' health and well-being, causing nearby areas to be less desirable for occupation and investment. These impacts result in price discounts. Hence, this research aims to establish the sensitivity of the property market towards Brownfield sites through a critical review. An overview of previous studies shows that property prices are sensitive towards Brownfield sites. This indicates that the proximity to a Brownfield site is considered when making property purchase decisions. Thus, property valuers, planners and developers should consider the Brownfield factor during property planning, development and valuation.
\end{abstract}

Keywords: Brownfield sites, house price, property market

\footnotetext{
${ }^{1}$ Lecturer at Universiti Teknologi Malaysia. Email: nurulhana@utm.my
} 
Nur Zafira Zihannudin, Nurul Hana Adi Maimun \&Nurul Liyana Ibrahim

Brownfield Sites and Property Market Sensitivity

\section{INTRODUCTION}

Brownfields are often linked with disadvantaged metropolitan areas, especially core cities and inner-ring suburbs that were intensively industrialised in the past (Davis \& Sherman, 2010). The rapid development of Malaysia has escalated the number of abandoned projects, including housing projects. It has been reported that there are 48 housing projects abandoned including 8,932 housing units in peninsular Malaysia (Ministry of Housing and Local Government, 2017). This issue becomes more severe due to the problems caused by Brownfields (Dahlan, 2011). Although the issue of Brownfield redevelopment has been raised since 2008, there are still many undeveloped areas (Nurlaila, 2014). To address Brownfield development, a guideline was published by the Town and Country Planning Department of Peninsular Malaysia to encourage the redevelopment of Brownfields. Several empirical studies on Brownfields show negative impact from Brownfield sites toward house prices with price discounts ranging from $2 \%$ to $8 \%$. Nonetheless, issues regarding Brownfields are still unclear (Han, 2014), yet Brownfields may have a dramatic effect on the adjacent property prices (Green, 2018). Due to the scarcity of research about the influence of Brownfield sites on property prices, regional planners lacked a clear foundation for assessing the future effect and redevelopment plans of such places.

Thus, this research will examine the influence of Brownfield sites on the property market. This review article will quantify Brownfield sites effect on the local property market and close the information gap that currently exists. The article is organised into five parts to facilitate the review. Brownfield locations are discussed in Section 2. Section 3 examines Brownfield sites' effect on property values. Section 4 covers the findings, while Section 5 addresses the conclusions and implications.

\section{BROWNFIELD SITES AND THE PROPERTY MARKET Brownfield Sites}

Brownfield sites are commercial or industrial assets that have been abandoned, deserted, dilapidated, or underutilised due to earlier acts that resulted in actual or perceived pollution and diminished redevelopment possibilities (National Round Table on the Environment and the Economy). In Malaysia, a Brownfield is an abandoned development area and obsolete development structure (JPBDSM, 2012) that may be contaminated (JPBDSM, 2012). Contaminated and derelict land in Malaysia can be found in abandoned rubber factories, automobile workshops, bus depots, fuel stations, industrial sites, landfills, oil depots, old mining sites, old railway yards and underground storage tanks sites (Yap, 2014). Industrial operations in the past have contaminated land areas with organic and inorganic toxins rendering them unsuitable for further growth, development, or reuse (US EPA). Brownfield sites are undesirable to developers owing to legislative uncertainty and high remediation expense (Wedding \& Crawford- 
PLANNING MALAYSIA

Journal of the Malaysia Institute of Planners (2021)

Brown, 2006). They entail a lengthy period of redevelopment and have poor demand from buyers. Brownfields are indicative of various issues that contribute to neighbourhood degradation, thwart revitalization initiatives, and result in drug activities, eyesores, fire dangers, rodent infestation and vagrancy (Cohen, 2001). Abandoned projects may also affect an area in various aspects, such as views and economic aspects (Ferber \& Grimski, 2002).

The Ministry of Housing and Local Government (MHLG) has highlighted that Peninsular Malaysia has a total of 281 private housing projects with 73,959 units abandoned for various reasons since 2009 to June 2020. As of December 2020, there was also a list of 187 blacklisted developers in Malaysia responsible for abandoned housing projects, which indirectly has jeopardised improvement efforts in the housing sector (MHLG, 2020). Besides this, a study by Arrifin and Abdul Razak (2019) inferred that the key factors leading to abandoned housing projects include the form of the contracts, bank funding, less engagement and subsequent project failure caused by lack of fairness in any business dealing or contract, and lack of an effective regulatory system. However, in 2019, fewer new launches and increased sales performance have resulted in a decline in residential overhangs and unsold, under-construction and not-yetconstructed units (Property Market Report, 2019). Residential overhang was reported to decline in 2019 after four consecutive years of growth, which indirectly led to decreased abandoned projects and avoiding accretion of vacant properties. In 2019, Malaysian property market performance improved slightly where there was a decrease of $5.1 \%$ in volume with 30,664 overhang units and $5.2 \%$ in value worth RM18.82 billion compared to 2018 . Only a slight increment in the total number of overhang units $(30,926)$ and value (RM19.99 billion) are observed for the year 2020 (PMR, Q3 2020).

For commercial properties in Malaysia, in particular shopping complexes, purpose-built offices and hotels were not spared from global market headwinds nor from the effects of the COVID-19 outbreak. Commercial property transactions decreased in volume by $10 \%$ and in value by $37.4 \%$ (PMR, Q3 2020). With the COVID-19 still taking place, it is expected that commercial properties will remain under pressure from 2021 onwards. As for future survival, older commercial buildings with high vacancy rate and low rental rate might need to opt for upgrading, refurbishment, repositioning or redevelopment instead of letting them be abandoned (PMR, 2019).

\section{Brownfield Sites Impact on the Property Market}

Property value is very sensitive to changes from the surrounding environment. Any changes in attributes may increase or decrease property value and changes in value are usually measured through the Hedonic Model (Adi Maimun, 2016). In general, property attributes can be grouped into locational, structural, and neighbourhood (Goodman, 1989; Williams, 1991). Structural attributes represent 
Nur Zafira Zihannudin, Nurul Hana Adi Maimun \&Nurul Liyana Ibrahim

Brownfield Sites and Property Market Sensitivity

the characteristics and conditions of the house. Structural attributes include age of building, floor area, kitchen cabinets, lot area, materials and finishing types, neighbourhood area, number of rooms, repair condition and structural condition (Adi Maimun, 2011). Structural conditions may affect house prices and rents positively or negatively. Meanwhile, neighbourhood attributes may include socio-economy, externalities, local authority services (Chin and Chau, 2003) and facilities (Roe et al., 2004). Residential areas with all facilities required will form a good property market (Nor Asmahan, 2012) as facilities provided enhanced economic activity of that area. The location factor lies in the bid-rent theory as theorised by Alonso (1964). Alonso's bid-rent theory puts forward that every agent is prepared to pay a certain amount of money, depending on the land's location. An attractively located property is highly sought after and pushes prices up through the bidding process. The location of a property mainly influences property purchase decisions and thus is reflected in property prices. Many people are ready to pay a premium for a desirable location (Prasad \& Richards, 2008).

Properties located near the city centre, for instance, will fetch high prices since many economic and business activities take place within the city centre area. In contrast, houses located farther from the city centre will decrease in price (Chin \& Chau, 2003). Brownfields also affect house prices. According to Accordino and Johnson (2000) and Doerle (2012), Brownfield sites cause economic, health, and environmental problems. A Brownfield imposes a significant externality on neighbouring property owners by lowering their properties' market value (Accordino \& Johnson, 2000). Brownfield's effects are most acutely felt in the residential sector due to the large number of consumers (buyers and renters) within the residential market segment. As a result, most research within this field has concentrated on the residential sector. Table 1 summarises previous research on Brownfield sites influence on residential property prices/rents. 
PLANNING MALAYSIA

Journal of the Malaysia Institute of Planners (2021)

Table 1: Previous Research on the Effect of Brownfield on Residential Property Value

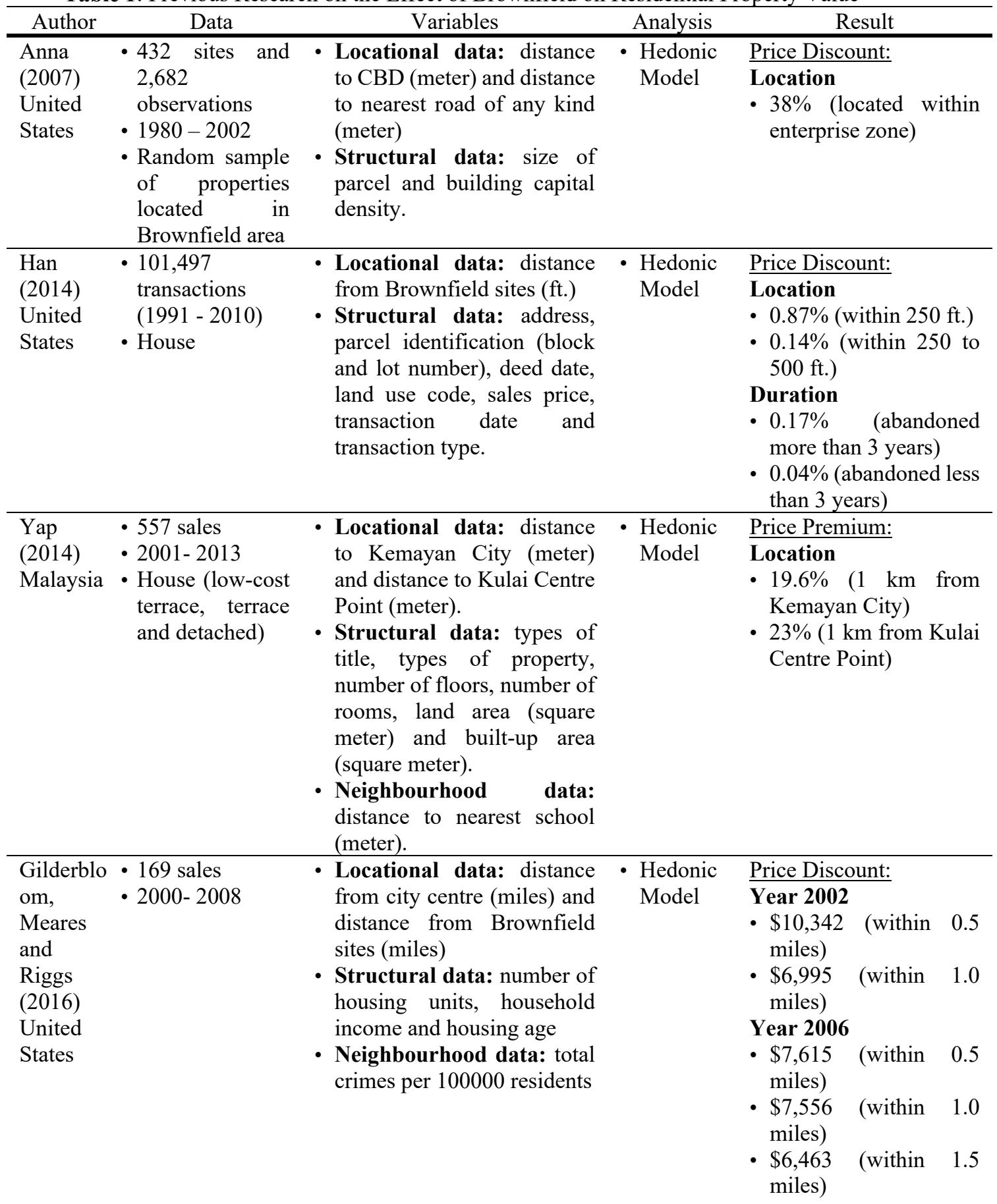




\begin{tabular}{|c|c|c|c|c|}
\hline & & & & $\begin{array}{lll}\text { Year 2008 } & & \\
\text { - } \$ 11,911 & \text { (within } & 0.5 \\
\text { miles) } & & \\
\text { - } \$ 9,757 & \text { (within } & 1.0 \\
& \text { miles) } \\
\text { - } \$ 8,261 & & \\
\text { miles) } & \text { (within } & 1.5 \\
& & \end{array}$ \\
\hline $\begin{array}{l}\text { Han } \\
(2017 a) \\
\text { United } \\
\text { States }\end{array}$ & $\begin{array}{l}\cdot 101,497 \text { sales } \\
\cdot 1991-2010 \\
\cdot \text { House }\end{array}$ & $\begin{array}{l}\text { - Abandoned property data: } \\
\text { address, parcel } \\
\text { identification number (block } \\
\text { and lot number), Vacant } \\
\text { House Notice first issued } \\
\text { and reissued dates, structure } \\
\text { type, lot area and tax } \\
\text { payment status (The Vacant } \\
\text { House File, The Baltimore } \\
\text { City Department of Housing } \\
\text { and Community } \\
\text { Development). } \\
\text { Structural data: address, } \\
\text { parcel identification (block } \\
\text { and lot number), deed date, } \\
\text { land use code, sales price, } \\
\text { transaction date and } \\
\text { transaction type. }\end{array}$ & $\begin{array}{l}\text { - Weighte } \\
\text { d Repeat } \\
\text { Sales } \\
\text { - Piecewis } \\
\text { e Linear } \\
\text { Regressi } \\
\text { on } \\
\text { Model }\end{array}$ & $\begin{array}{l}\text { Price Discount: } \\
\text { Location } \\
\text { - } 1.5 \% \text { (within } 250 \mathrm{ft} \text {. on } \\
\text { second sales) } \\
\text { - } 1.0 \% \text { until } 2.7 \% \text { (more } \\
\text { than two nearby } \\
\text { abandoned properties } \\
\text { between the first and } \\
\text { second sale) }\end{array}$ \\
\hline $\begin{array}{l}\text { Han } \\
\text { (2017b) } \\
\text { United } \\
\text { States }\end{array}$ & - House & $\begin{array}{l}\text { - Neighbourhood data: level } \\
\text { of social organisation, } \\
\text { neighbourhood } \\
\text { disadvantage, level of } \\
\text { government intervention } \\
\text { and neighbourhood housing } \\
\text { market characteristics. }\end{array}$ & $\begin{array}{l}\text { - Hedonic } \\
\text { Model }\end{array}$ & Price Discount: $1.384 \%$ \\
\hline $\begin{array}{l}\text { Schwarz, } \\
\text { Gill, } \\
\text { Hanning } \\
\text { and Cox } \\
\text { (2017) } \\
\text { United } \\
\text { States }\end{array}$ & $\begin{array}{l}\cdot 18,109 \text { sales } \\
\cdot 1997-2005 \\
\cdot \text { House }\end{array}$ & $\begin{array}{l}\text { - Locational data: Distance } \\
\text { from the nearest Brownfield } \\
\text { - Structural data: air } \\
\text { condition, age of building, } \\
\text { lot area, number of } \\
\text { bathrooms and bedrooms } \\
\text { and sale prices. }\end{array}$ & & $\begin{array}{l}\text { Price Discount: } \\
3 \% \text { (within } 0.5 \text { miles) } \\
5 \% \text { (within } 1 \text { miles) }\end{array}$ \\
\hline
\end{tabular}

The increment of foreclosures, empty, and abandoned homes in a nation resulted in a substantial amount of research and empirical studies estimating the negative spillover effects of distressed homes in a neighbourhood (Frame, 2010; Joice, 2011). Overall, the body of research used the Hedonic model to establish a relationship between Brownfields and house prices. This method is popularly used as it can quantify the effect of each characteristic on the overall house price 
PLANNING MALAYSIA

Journal of the Malaysia Institute of Planners (2021)

(Asmawi et al., 2018; Rahman et al., 2019). A study conducted in the United States by Anna (2007) uses 432 sites and 2,682 observations from 1980 to 2002. This research scope is focused on contaminated sites obtaining a random sample of properties in the Brownfield region with comparable land-use limitations. Anna (2007) concluded that parcel transactions in an enterprise zone are discounted by $38 \%$.

Nonetheless, association is statistically insignificant. Properties that have been vacant for more than three years diminished nearby property values within $250 \mathrm{ft}$. by $1 \%$, within 251 until $500 \mathrm{ft}$. by $0.27 \%$, within 501 until $1000 \mathrm{ft}$., by $0.05 \%$ and within 1001 until $1500 \mathrm{ft}$., by $0.14 \%$ (Han, 2014). In 2017, research based in the United States by Han (2017a) observed that at the second sale, one abandoned property located within $250 \mathrm{ft}$. dropped surrounding property values by $1.5 \%$. Between the first and second sales, more than two number of neighbouring abandoned properties would result in a fall in property prices of between $1.0 \%$ and 2.7\%. In another research, Han (2017b) included the neighbourhood factor through neighbourhood level of social disorganisation, neighbourhood concentrated disadvantage, level of government intervention and neighbourhood housing characteristics. Through multiple regression analysis (MRA) and using 510 transaction sales in the United States, the research shows that there is a price discount of $1.384 \%$. Gilderbloom et al. (2016) examined the impact of EPA Brownfield sites between 2000 and 2008 on house prices, foreclosures, and early death in Louisville, Kentucky. They observed that residences within a half-mile radius of Brownfield sites were worth $\$ 10,342$ less in 2000. When the radius is enlarged to a mile, the value of homes inside the radius is $\$ 6,995$ less than those outside. In 2006, homes situated within a halfmile of a Brownfield site were worth $\$ 7,615$ less than those farther away. Within a mile, houses were valued $\$ 7,556$ less than other residences. Within a mile and a half, houses were valued $\$ 6,463$ less. In 2008 , the trend persisted. Properties within a half-mile of the site were worth an average of $\$ 11,911$, less than homes within a mile, which were worth an average of $\$ 9,757$ less. The latter were valued less than properties located a mile and a half away. Homes inside this radius were $\$ 8,261$ less valuable than those beyond it.

Meanwhile, Schwarz et al. (2017) found that properties located 0.5 miles from the nearest Brownfield experienced a $3 \%$ decline in sales value for a 10,000 square feet sized Brownfield. When discrete distances were considered, Brownfield size had a negative effect on property prices up to one mile $(0.6 \%$ to $3.1 \%)$. In Malaysia, research on Brownfields was conducted by Yap (2014) where 557 transaction sales between 2001 to 2013 were analysed. Yap (2014) found an increasing house price of $19.6 \%$ for residential areas located 1 kilometre from Kemayan City, an abandoned shopping complex. For residential areas located 1 kilometre from Kulai Centre Point, house prices increased by $23 \%$. 
Nur Zafira Zihannudin, Nurul Hana Adi Maimun \&Nurul Liyana Ibrahim

Brownfield Sites and Property Market Sensitivity

\section{DISCUSSION}

The majority of the literature centres on Brownfield redevelopment complexities. Only a few empirical studies examined Brownfields effect on residential property value. The scarcity of research on the Brownfields impact on residential property values may add to the difficulty of Brownfield redevelopment. Moreover, most studies were based in the United States. The lack of relevant empirical research in Malaysia raises the question whether Brownfield sites will impact the property market and, if so, what the magnitude of impact would be. The lack and uncertainty of market information affects the property market player's decision making such as valuers in valuing property prices and developers in developing areas. Therefore, there is a need for a study to establish Brownfield impacts on residential property value, particularly in Malaysia.

\section{CONCLUSION}

This paper established a few key findings related to the Brownfield sites impact on property prices. The study concluded that the impact of Brownfield sites on the property market varies depending on the situation. The various impacts of Brownfield sites on property prices highlights the need for a local based study, particularly in Malaysia given the quantity of abandoned properties that exist. The research findings contribute to the clarification of the Brownfield sites' impact on property market literature. Property market players such as valuers, planners and developers may find the findings beneficial in making various decisions related to property such as planning, developing and valuing properties.

\section{ACKNOWLEDGEMENT}

The authors want to convey their thanks to the research funders, namely Ministry of Higher Education Malaysia through Fundamental Research Grant Scheme (FRGS/1/2019/SS08/UTM/02/7) and Universiti Teknologi Malaysia through Research University Grant (GUP Tier 2) (Q.J130000.2652.16J56). Additionally, the writers would like to convey their heartfelt thanks for the helpful remarks and ideas of the reviewers in improving the quality of this article.

\section{REFERENCES}

Accordino, J., and Johnson, G. T. (2000). Addressing the vacant and abandoned property problem. Journal of Urban Affairs, 22(3), 301-315.

Adi Maimun, N. H. (2011). Spatiotemporal Autoregressive Model for Malaysian Housing Market Analysis (Master dissertation, Universiti Teknologi Malaysia).

Adi Maimun, N. H. (2016). Price and Rent Effects of Energy Efficiency in Residential Properties: Evidence from the Belfast Metropolitan Area (Doctoral thesis, University of Ulster).

Anna, A. (2007). Determinants and effects on property values of participation in voluntary cleanup programs: The case of Colorado. Contemporary Economic Policy, 25(3), 415-432 
Arrifin, N. M. and Abdul Razak D. (2019). Perception of Stakeholders on Abandoned Housing Projects in Malaysia. International Journal of Islamic Economics and Finance, 2(1), 131-148.

Asmawi, M. Z., Mohit, M. A., Noor, N. M., Abdullah, A., \& Paiman, T. (2018). Factor analysis on hedonic pricing model on open space affecting the housing price in Melaka and Seremban. Planning Malaysia Journal of the Malaysian Institute of Planners, 16(2), 119-130.

Cohen, J. R. (2001). Abandoned housing: Exploring lessons from Baltimore.

Chin, T. L. and Chau, K. W. (2003). A Critical Review of Literature on the Hedonic Price Model. International Journal for Housing Science and its Applications, 27(2), 145-165.

Dahlan, N. H. M. (2011). Rehabilitation of abandoned housing projects: a comparative analysis between the law and practice in Peninsular Malaysia and the Republic of Singapore. Commonwealth Law Bulletin, 37(1), 145-173.

Davis, T.S., Sherman, S.A., 2010. Brownfields: A Comprehensive Guide to Redeveloping Contaminated Properties. American Bar Association, Chicago, IL.

Doerle, J. M. (2012). Economic perspectives of Brownfield development in Germany: an integrated approach. Stuttgart: Department foe Environmental Protection, Germany.

Ferber, U. and Grimski, D. (2002). Brownfields and Redevelopment of Urban Areas. Report from the Contaminated Land Rehabilitation Network for Environmental Technologies, CLARINET. pp 1.

Frame, W. S. (2010). Estimating the effect of mortgage foreclosures on nearby property values: A critical review of the literature. Economic Review, 95(3), 1-9.

Green, T. L. (2018). Evaluating predictors for Brownfield redevelopment. Land Use Policy, 73, 299-319.

Gilderbloom, J. I., Meares, W. L., and Riggs, W. (2016). How Brownfield sites kill places and people: an examination of neighborhood housing values, foreclosures, and lifespan. Journal of Urbanism: International Research on Placemaking and Urban Sustainability, 9(1), 1-18.

Goodman, A. C. (1989). Topics in Empirical Urban Housing Demand. In Goodman, A.C., Muth, R.F. (Eds.) The Economics of Housing Markets. London: Harwood Academic Publishers.

Han, H. S. (2014). The impact of abandoned properties on nearby property values. Housing Policy Debate, 24(2), 311-334.

Han, H. S. (2017a). Exploring Threshold Effects in the Impact of Housing Abandonment on Nearby Property Values. Urban Affairs Review, 1078087417720303.

Han, H. S. (2017b). Neighborhood characteristics and resistance to the impacts of housing abandonment. Journal of Urban Affairs, 39(6), 833-856.

Jabatan Perancang Bandar dan Desa Semenanjung Malaysia (2012) Garis panduan perancangan pengenalpastian bagi pembangunan semula kawasan Brownfield. Jabatan Perancangan Bandar dan Desa Semenanjung Malaysia, Kuala Lumpur.

Joice, P. A. (2011). Neighborhood stabilisation program. Cityscape, 13(1), 135-141.

National Round Table on Environment and The Economy (NRTEE), 2013. 
Nur Zafira Zihannudin, Nurul Hana Adi Maimun \&Nurul Liyana Ibrahim

Brownfield Sites and Property Market Sensitivity

Nor Asmahan, A. (2012). Faktor-faktor Yang Mempengaruhi Kenaikan Harga Harta Tanah Kediaman di Daerah Kota Setar, Kedah (Doctoral dissertation, Universiti Teknologi Malaysia).

Nurlaila, A. (2014). Pembangunan semula Brownfield bagi memenuhi konsep lestari (Doctoral dissertation, Universiti Teknologi Malaysia).

Prasad, N. and Richards, A. (2008). Improving Median Housing Price Indexes through Stratification. Journal of Real Estate Research, 30(1), 45-72.

Property Market Report (2019). Valuation and Property Services Department Malaysia. Ministry of Finance Malaysia.

Property Market Report (Q3 2020). Valuation and Property Services Department Malaysia. Ministry of Finance Malaysia.

Rahman, S. N. A., Adi Maimun, N. H., Razali M. N. \& Ismail, S. (2019) The Artificial Neural Network Model (ANN) for Malaysian Housing Market Analysis. Planning Malaysia Journal of the Malaysian Institute of Planners, 17(1): 1-9.

Roe, B., Irwin, E. G., Hazel, A., and Jones, M. (2004). The Effects of Farmland, Farmland Preservation, and Other Neighborhood Amenities on Housing Values and Residential Growth. Land Economics. 80(1), 55-75.

Schwarz, P. M., Gill, G. L., Hanning, A., and Cox, C. A. (2017). Estimating the effects of Brownfields and Brownfield remediation on property values in a new south city. Contemporary Economic Policy, 35(1), 143-164.

Wedding, G. C., and Crawford-Brown, D. (2007). Measuring site-level success in Brownfield redevelopments: A focus on sustainability and green building. Journal of Environment Management, 85, 483-495.

Williams, A. (1991). A Guide to Valuing Transport Externalities by Hedonic Means. Transport Review, 11(4), 311-324

Yap, W. W. (2014). The Impact of Brownfield on Residential Property Value. Universiti Teknologi Malaysia.

Received: $17^{\text {th }}$ May 2021. Accepted: $9^{\text {th }}$ July 2021 